\title{
Housing supply, investment demand and money creation - a comment on the drivers of London's housing crisis
}

This commentary examines the current emphasis on supply-side solutions to London's housing crisis building more homes to increase accessibility - against a backdrop of intensifying demand-side pressures, the financialisation of housing, and the impact of credit liberalisation and money creation on housing demand and prices. It reflects on the need to balance additional housing supply, where needed, with demand-side measures that acknowledge the centrality of spatially unbounded investment demand and the flow of money created by deregulated banks into housing as fundamental to the current crisis of housing affordability and access.

\section{Accepted, Urban Studies, $27^{\text {th }}$ March 2017}

\section{Introduction}

There is broad agreement that England is facing a housing crisis, centred on London. It is also agreed, by a range of commentators from across the political spectrum, that this crisis is rooted in housing undersupply: not enough homes have been built in the right locations for a number of years (Lyons, 2014; Bowie, 2017). In response, those on the left have called for an enlarged public sector presence in housing production: that is, a return to building 'council houses' (Healey, 2015). In contrast, voices on the right have tended to present land-use policy as the principal cause of the current predicament, pitching the blame for 'market failure' (in housing supply) at the planning system (Hilber, 2015) and asserting that only through reduced regulation and the general removal of land-use constraint will the current crisis be eased.

Through an examination of the broader political economy of the crisis, this commentary aims to show that housing supply is but one lever amongst many that will need to be pulled if England's broken housing market is to be fixed. London provides the main focus as it is here, and across the wider south east of England, that housing inequality, and access pressures are most acutely felt (Dorling, 2014; Edwards, 2016). London is also the point of strongest connection with the global movement of wealth (Atkinson et al, 2016) which has now become another shaper of England's housing market (Rossall Valentine, 2015) and part of the broader political economy of its housing system. A London focus also links the analysis presented here to similar situations in other late-industrial economies. Regular international market appraisals from Knight Frank (see 2016 for the most recent) highlight many examples of price inflation running far ahead of real earnings, fuelled by historically low interest rates and the global movement of capital into safe investment havens. Countries as diverse as Sweden, New Zealand, Canada and Hong Kong are singled out as popular investment destinations. The crises that such countries now face appear to be commonplace (Aalbers, 2016) and link to the wider economic and banking disruptions (Turner, 2008; Harvey, 2013) that precede falling interest rates and a rush of investment capital into fixed assets commercial and residential property.

The commentary runs as follows: after a general introduction it examines the current emphasis on supplyside solutions to the housing crisis; it then looks at demand-side pressures before turning attention to the financialisation of housing (broadly, the changing economic role of housing in national economies and its transformation into high-quality collateral, supported by deregulation, by mortgage-lending practices, by the securitization of mortgage debt, and by new patterns and opportunities for investment - see Edwards, 2002; Aalbers, 2016) and the impact of money creation on the demand for housing. The commentary ends with reflections on balancing additional housing supply, where needed, with other market 
interventions that acknowledge the centrality of spatially unbounded investment demand and the flow of money created by deregulated banks into housing as fundamental to the current crisis of housing affordability and access.

\section{Housing crises}

Periodic housing crises are a persistent feature of late industrial economies in which housing has become a focus of profit-taking from fixed assets (Edwards, 2002) and therefore commodified in its use and financialised in its consumption (Aalbers, 2016). Whilst national or local crises are products of their own contexts, they are often built on remarkably similar foundations. Capital accumulation in, and through, housing (Piketty, 2014) often signals a decline in more productive economic activities, with housing becoming an attractive asset-class to both domestic and international investors. As domestic investors turn away from other assets and footloose global capital seeks new opportunities, bounded local supply (that is, bounded in geographical space) tries and fails to keep pace with unbounded investment demand with its multiple domestic and non-domestic sources. Systems of supply (contract or speculative) may struggle against land and regulatory constraints (Gurran et al, 2016), but it is the financialisation of housing and sharply increasing levels of investment demand (driven by an economic imperative) that represents - in our view - at least as great a struggle.

Systems of supply are being called upon not merely to deliver against housing need but rather to satisfy a much broader demand. Their failure to keep pace with demand (resulting in scarcity) reinforces the status of housing as high-quality collateral, but this is not the root cause of financialisation. What is happening to housing today, in England and elsewhere, is driven by factors that transcend national borders and that overwhelm local interventions either because investment pressures are simply too strong or economies too dependent on the collateral effect of housing consumption.

In England, although these patterns of consumption, investment and financialisation touch all parts of the country, media attention has been focused on London. One marker of the housing crisis has been the 7\% decline in home-ownership since 2003 (DCLG, 2016a). Encouraging and facilitating the advance of a 'property owning democracy' (Jackson, 2005) has been a central plank of housing policy for decades. The spectacle of more households - especially younger ones - failing to get onto the housing ladder and therefore languishing in a largely under-regulated private rented sector has fed a rhetoric of declining housing 'affordability'. Whilst housing charities highlight the need for action across different tenures new investment in public and third sector accommodation and interventions in the private rented sector aimed at delivering stability in rents and consistency in quality - government policy remains focused on the promotion of home-ownership through channelling subsidy to aspiring first-time buyers. The prospect of young people being locked out of the market and not sharing in the opportunities enjoyed by their parents is an emotive and popular strand of current debate. A 'weak supply' explanation for this situation is equally popular and rests on two widely quoted government datasets: new housing completions (143,530 in 2015; DCLG, 2015b) and the rate of household formation (210,000 per year, according to the latest government figures, DCLG, 2016c). These are equated, respectively, with housing supply and demand and - under the terms of this explanation - it is undeniably the case that the production of new homes has not kept pace with the formation of new households in England. There has been constant reference to this mismatch for at least the last 20 years (see Breheny and Hall, 1996).

But as an aggregate expression of housing need and demand household projections are inadequate. Whilst they provide some indication of the scale of housing requirement and changes year-on-year, their attempt to capture both housing need and 'effective demand' (Holmans, 2014) is questionable. The full extent of need is hidden in trend data as the apparent unavailability of housing suppresses household 
formation (Whitehead, 1991; Meen, 2011). Similarly, whilst demand is assumed to be restricted to that generated by household formation (underpinned by population increases and permanent immigration) the actual sources of that demand, as noted above, are far more diverse. Whitehead (2016) observes that demographic and economic data must be brought together if projections are to provide a useful indication of future housing requirement. Demographic data point to a housing requirement in the mid200,000s in England (Lyons, 2014; DCLG, 2016c), but add in economic (demand) drivers and the new-build figure needed to stabilise real house prices relative to earnings is in the region of 400,000 per annum (Whitehead, 2016: 419). Put simply, the broader composite of demand - built on investment buying and the aforementioned collateral function of housing - suggests a huge supply challenge if the sole response to the crisis is just to build more homes.

\section{The emphasis on housing supply}

Housebuilding in England often proceeds at a 'glacial' pace (Hall, 2014: 67) and supply is less responsive to demand than in other parts of the world (Gurran et al, 2016). However, these observations do not support the conclusion that increased supply, alone, will make housing - to rent and buy - affordable enough to be more broadly accessible. The 'supply-side fetish, in which incentivised developers and overhauled planning laws create enough housing for all' (Williams, 2016) is seductive, offering a clear way forward. But it is rooted in the same structure of belief - the 'myth of rational markets' - that led US policy-makers to ignore the concentration of wealth, and over-investment, in residential property that precipitated the global financial crisis (Frydman and Goldberg, 2008). That crisis was founded upon deregulation (e.g. banking and credit liberalisation) and associated investor behaviour. The devotion to supply-side measures translates into an extension of financial deregulation to planning systems and landuse policy: neoliberal answers to neoliberal crises, which ignore the concentration of power in the hands of property owners and the way such concentration, and flows of unregulated capital drive the demand and ultimately the price of housing.

Cheshire and colleagues have shaped long-standing arguments concerning the downsides of restricting space for housing (e.g. Evans, 1991) into a powerful critique of the role of planning in constraining housing supply and reducing affordability. These arguments have gained traction with right-of-centre think-tanks (Niemietz, 2014) and contributed to the development of government policy (Hilber and Vermeulen, 2010). London's Metropolitan Green Belt has been singled out as a brake on land supply and therefore a driver of rising house prices: indeed, like 'works of art', land has become '[...] an asset for which there is an underlying consumption demand but which is in more or less fixed supply' (Cheshire, 2014: 16). Constraints on land supply, often justified for reasons of 'urban containment' and densification, are credited with turning housing into an especially attractive asset-class. It is agreed that household projections provide inadequate means of forecasting the requirement for housing (Cheshire et al, 2014) and that incomes provide a clearer signpost to future levels of consumption. As incomes rise so does the consumption of housing space: buyers want more rooms, bigger rooms and the status that housing confers on those who can afford it (see also Tunstall, 2015). But whilst reliance on incomes as a basis for forecasting 'requirement' makes intuitive sense, as an argument it must contend with the reality, in recent years, of significant increases in house prices (a 41\% increase since 2008 across the UK; ONS, 2016) running alongside declining incomes (a drop of $10 \%$ in median real weekly earnings over the same period; Machin, 2015). Since the financial crisis, there has been - to some extent - a decoupling of incomes from house prices, with the latter driven not by increases in real earnings but by new patterns of consumption including the leverage of existing housing wealth (in the hands of investors, ranging from buy-to-let landlords and a global elite; Dorling, 2014; Atkinson et al, 2016) to purchase additional property, pushing prices beyond the reach of first time buyers, and concentrating housing wealth in fewer hands. 
More generally, the case for deregulation is predicated on the belief that housing and planning policy should relegate the broader need to be housed behind a rising demand for private home-ownership, always viewing housing as a market commodity rather than a social good to be delivered in a range of marketised and non-marketised ways. What is offered by the supply-side preoccupation is a partial political economy of housing, with consumption demands pitted against an opposition to development (instrumentalised through planning) which often seeks to defend property values.

All perspectives on planning and land supply are value-laden and '[...] any coherent housing policy must undoubtedly include clearly understood value judgements about the special nature of housing' (Whitehead, 1991: 885 emphasis added). Interventions in land markets and regulations affecting demand (e.g. through taxation) are frequently dismissed as disruptive and ideological. In contrast, deregulation and relaxation are presented as a more 'natural' state of affairs, as anti-ideological and less synthetic (see, for example, Cameron, 2009). But whichever direction is taken, powerful values and ideas, coalescing into ideologies, drive the housing system and the outcomes it generates. For example, recognition of the 'special nature of housing' could see it removed from the market, delivered instead as a social good to which rights of access are attached. On the other hand, its special nature might be defined by its economic function (a magnet for investment and collateral for borrowing), resulting in a policy framing that seeks to preserve and promote that function (with increased financial incentives and policies such as help-tobuy).

This is the current situation: supply perspectives are focused on servicing the effective demand for housing that can be discerned within the resident population; this is married with a relaxed attitude to external demand pressures and, until very recently, generous tax relief for those investing in buy-to-let property. But the land-use deregulation that supply proponents call for seems incapable of keeping pace with the demand pressures generated by deregulation elsewhere. Preservation and extension of housing's economic function means risking environmental damage (by focusing primarily on new-build) and rejecting significant demand-side interventions with the potential to calm price inflation. Debates around the recent 'help-to-buy' scheme - equity loans for some first-time buyers - capture some of these tensions. Government-sponsored research has shown that the loans have stimulated the supply of new homes (DCLG, 2016d) and the Bank of England is satisfied that they present no danger of a return to riskier lending practices. However, the IMF has drawn attention to the inflationary pressures that demand-side support may generate (Giles, 2013) whilst RICS and others fear that public finances are becoming too locked into, and dependent on, house price growth (see RICS, 2014).

\section{Investment demand in the wider political economy of housing}

Housing supply is necessarily finite (even if one believes that London's green belt is too tightly drawn; see Mace et al, 2016) whereas the demand for housing, in a global market-place, is not spatially bounded (there are multiple geographical sources of that demand). The directions in which capital (and housing demand) flows are determined by degrees of political stability and by local rules pertaining to property rights and tax liability (the freedoms and incentives to invest). In this context, the supply preoccupation is a distraction, limiting consideration of policy measures that might mediate demand, reduce economic dependence on house-price inflation, and refocus upon the desired function of housing (as a social as well as an economic good) and whether policies supporting a more balanced view of that function are workable. A point has been reached in policy discourse where the elimination of barriers to increased housing supply appear to be the only show in town, supported by a partial political economy that frames housing as an investment choice shackled by bureaucracy in the form of land-use planning. That perspective underplays the significance of capital flows, credit liberalisation, monetary policy, and government support for housing demand in producing housing outcomes. 
The most important of these outcomes is a new relationship with housing. That relationship has been manifest in solid house-price growth and in new patterns of housing consumption: from domestic buyers moving their capital into bricks and mortar (and levering loans from rental income) to overseas buyers 'parking' money in key investment destinations. Barker (2014) makes the important point that the prospect of 'reasonable investment return' is a motivating factor in all private housing consumption. The investment motive is not new and underpins the preference for home-ownership. But in some forms of consumption, the investment motive is more conspicuous and dominant. There is currently burgeoning interest in foreign investment in globally-connected cities - including London - not necessarily because that investment is seen as an over-riding driver of national housing outcomes but because it signals the change in the function of housing and a new pattern of financialised consumption (Fernandez et al, 2016).

London's prime property markets have always attracted international investors (first from the Middle East and more recently from Russia and the Far East) and those markets are now extending to new residential developments at Canary Wharf and back along the Thames riverside to Battersea (and its new Embassy Quarter) and beyond. Global capital's appetite for investment in London is expressed in the phenomenon of 'iceberg houses': excavations under homes in some of the city's most exclusive postcodes, designed to increase value rather than produce useable living space. Such conspicuous consumption might be dismissed as being merely symptomatic of London's world city status. Likewise, the housing crisis is simply a product of more people wanting to live and work in the city than can be accommodated, triggering price rises. In other words, these are all inevitable effects of London's success as a world city.

Also, the markets occupied by high and ultra-high net worth individuals and 'ordinary' homebuyers are decoupled, so building more homes for the latter will ease pressure. But these markets are not separate entities. Although much prime property is offered overseas and off-market (direct from the developers), it is squeezed into the same bounded space; it subtracts from the same available land supply; and it diverts demand in other sections of the market elsewhere. Hence, there is a ripple effect observed in house prices across London, from the traditional prime locations to popular suburbs, newly gentrifying neighbourhoods, and outwards into nearby commuter regions. Whilst London is at the sharp end of investment pressures, attracting a high proportion of overseas buyers and buy-to-let interest, the impacts of investment and residential displacement are felt more widely. Meen (2011) observes that London's housing market now tracks investment behaviour to a greater extent than movements in earnings.

Weak housing supply, where it occurs, of course amplifies the effects of these pressures, but the pressures themselves are attributable to both a 'wall of global capital' (Aalbers, 2016: i) seeking high-quality collateral and to new patterns of domestic housing consumption. Broader than the concentrated frenzy of overseas investment buying is the growth of the 'buy-to-let' phenomenon (Turner, 2008; Bank of England, 2015b). Although foreign buyers are also involved in this segment of the market, 'buy-to-let' is principally a business or income supplement for domestic investors, some of whom worry about the future value of their pensions (Edwards, 2015) given the reliance of those pensions on the performance of stock market assets. One of the peculiarities of the UK housing system is the rapid expansion of amateur landlordism. This expansion began in the late 1980s with the creation of more flexible (and short term) tenancy arrangements. Further deregulation of mortgage lending in the 1990s fuelled growth in the market. Today, a great many amateur landlords secure both capital appreciation and rental yields from buy to let property, pumping much of this new private wealth back into further housing consumption and investment (Aoki et al, 2001). 
In the 1990s, much of the capital flowing into housing was released by bank and credit liberalisation; today, access to credit, like wealth in general, is more concentrated in the hands of existing home-owners or propertied interests who sustain high levels of market transaction through cash-buying (Bank of England, 2015a) and out-compete less prosperous groups, consigning a growing section of the population to a largely unregulated and unstable rental sector (Kemp and Kofner, 2010).

The open nature of the housing market means that prices, and underlying residual land values, are set by an extraordinarily high level of demand. If that demand-were removed or restricted, prices (and land values) would be determined by a far lower demand sub-set. Developers of prime housing sites would be left high and dry, unable to recover land costs. But in the current unrestricted market, those costs are recovered by building for the highest end of the market to the complete exclusion of family or affordable housing (Hunter, 2016). Where a proportion of the latter is required as part of a planning agreement, developers will offer payments in lieu of on-site contributions because of the unacceptable cost of losing space in a prime location. These economic drivers tend to result in concentrations of investment housing, the purchase of which often happens off-plan. Properties may change hands before they are built (or the development even commences), potentially causing a further bidding up of prices (White, 2015) and increasing market volatility as patterns of investment follow the herd behaviour normally associated with non-fixed assets.

\section{The financialisation of housing and money creation}

The popularity of housing as high-quality collateral can be explained by its long-term performance as an investment asset, performing best under conditions of political stability and in contexts where planning seeks to balance the need for development with a range of environmental and social considerations. Planning, as such, has a role in constraining the supply of built assets. This is undeniable. But the financialisation of housing has drivers which are separate from the constraint on supply produced by planning systems. Financialisation is rooted in the way housing is built and sold, credit liberalisation, money creation and in the deregulated banking sector.

The financialisation of housing has causes which are shared between countries, but there are also placespecific triggers that have either accelerated the process or given it localised characteristics. In the UK, home-ownership has been actively encouraged for the last half a century. Renting has been denigrated as an inferior tenure that does not provide a context for household or family stability, and will not provide a vehicle for the inter-generational transfer of wealth. These are key functions of privately-owned housing and, in more recent times, the idea that wealth is simply transferred on to the next generation has been supplanted by the security of wealth (equity) being accessible to meet unexpected costs in later life or as pension replacement (Barker, 2014; Edwards, 2015). People now view housing as a source of wealth creation, using the property they already own as security for the loans needed to acquire additional property. Housing serves a triple financial function: wealth creation, wealth transfer and either welfare safety net (for poorer owners) or a significant pot of equity after retirement (for wealthier owners).

Under previous credit arrangements (more conservative patterns of lending and borrowing) house prices in the UK were driven up, in part, by the way housing is built and sold. Production is 'speculative' rather than 'contract', meaning that its building is not contracted by a known buyer. Rather, it is built for an estimated market and, ahead of completion, prices are set by the level of expected demand. For that reason, there is an underlying rationale, particularly for the speculative builders, to trickle supply onto the market and release it when demand (or market) conditions are most favourable to producers - increasing profit at the expense of construction volumes (Payne, 2013). 
However, credit (and the flow of money into housing) has a greater effect on prices and is a more important component of the financialisation of housing (Turner, 2008). In the aftermath of the 2008/9 Global Financial Crisis, greater attention was given to the channels by which credit affects price (Duca et al, 2010) and how easier access to loans (as banks prioritise lending on real estate) resulted in a pattern of 'over-investment' (initially in the US sub-prime market) that over-inflated personal debt to the point where it was unsustainable and banks were unable to retrieve the cost of 'bad loans' from foreclosure and onward sale. Housing had become financialised to the point that the value of the fixed asset bore no relationship to the size of the debt attached to it. The results are well-known: this level of over-investment had global ramifications and underscored the vulnerability of banks and national economies which 'implicitly treat housing markets as liquid and efficient' (Duca et al, 2010: 204). Banks have played a central role in the financialisation of housing. Their lending decisions have decoupled the value of property from earnings. And the deregulation of that lending (specifically, the removal of rules requiring a balance between money lent and deposits; Wainwright, 2009) has led to a situation in which money is 'created' on spreadsheets to match the supposed value of a house. 'Whenever a bank makes a loan, it simultaneously creates a matching deposit in the borrower's bank account, thereby creating new money' (McLeay et al, 2014: 1). It is the deregulated supply of money to the economy by banks (at the start of the global financial crisis, just $\mathrm{f1.25}$ was held in deposit by UK banks for every $f 100$ advanced as credit: Ryan-Collins et al, 2012) and therefore the rapid (and seemingly easy) supply of that money relative to the slow (and seemingly difficult) supply of homes (that is, the supply of existing properties coming onto the market plus new-build, the latter representing less than $1 \%$ of supply each year) that underpins financialisation and systemic risk. Housing is produced that is not 'needed' in - in the sense of being someone's home - and only exists to store (or capture, from the perspective of national economies) newly created money or wealth imported into the country.

Banks are of course profit-seeking entities and during periods of economic stability, they are naturally eager to lend to the extent that money creation soars, house prices rapidly inflate and instability arises from over-investment. Jordá et al (2011) have been able to show, using long-run data from fourteen advanced economies between 1870 and 2008, that 'credit growth generates the best predictive signals of financial instability' (p. 373): indeed, the long-run record shows that recurrent episodes of financial instability have more often than not been the result of credit booms gone wrong (p. 369). In the run-up to the Global Financial Crisis, the banking sector more than doubled the supply of money to the property market and financial sector, causing an escalation of demand for high-quality collateral assets and drawing in new speculators. A self-reinforcing inflationary process set in, with the increase in demand for such assets further driving up their price, which in turn generated an upward spiral of borrowing and price inflation.

The behaviour of banks can help skew an economy towards housing dependency and away from business or manufacturing growth. The way in which money is created means that banks display a clear preference for lending against high-quality collateral: that is, property and the land it sits on. If a business fails then money lent by a bank to support it is lost. If, on the other hand, a homebuyer defaults on a mortgage, the bank recovers and sells on the property in a market where prices are set by the credit liberalisation of which it is a part. The bank may well profit from the default, enjoying the equity growth now lost to the former mortgagee. But in order to avoid this situation becoming a norm, or just too regular an occurrence, interest rates are set to make loans as accessible and as affordable as economic circumstances permit. In fact, they frame this housing-led model of economic growth. The economy needs large numbers of mortgaged households servicing housing debt and maintaining the cycle (and investment incentive) of house-price growth. Significant falls in the incomes needed to service loans, or big increases in monthly 
mortgage repayments because of rising interest rates, would stall the system resulting in a recession in spending.

\section{Conclusions}

In this commentary, we have dealt with three major themes: the preoccupation with demand-side explanations of the English 'housing crisis' focused on London; the importance of investment demand in shaping patterns of consumption; and the way housing has become 'financialised', providing collateral for money and wealth creation. Two important observations have been made, which are central to the current crisis: first, the absolute supply of housing is limited (by land supply and socio-political constraint) in a way that investment demand - domestic and international - is not; second, banking deregulation has led to a situation in which the supply of money into the economy appears infinite, causing mortgage lending to outpace the reasonable supply of new homes or the release of second-hand property onto the market. These processes support the creation of wealth but not the distribution of housing against need. Central to this predicament is the view that markets are a means of delivering generalised benefits and that wealth creation is a public good, irrespective of how that wealth is created or distributed. This thinking, and this system, is now deeply embedded in the UK economy. The banking system is housingdependent; it cannot countenance significant falls in prices or disruptions in the pattern of lending. Alongside that system is a complex array of institutions and financial services that are directly or indirectly dependent on the housing market continuing to operate as it currently does. Even more broadly, the wealth and wellbeing of the majority of households in England appears dependent on the confidence that equity growth in housing provides. Economic growth or recessions in spending are inexorably tied to shifts in house prices. This broader economic dependence is the clearest sign of the deeper financialisation of housing. Yet it seems peculiar that economic confidence should depend on the level of national private debt and one wonders whether greater freedom from that debt - delivered by lower house prices and smaller repayments on loans - would not release more money into the economy for other sorts of spending and productive lending. However, this could not be achieved in the short term by falling house prices. A sudden crash in prices would plunge many households into negative equity, triggering personal, political and economic turmoil.

Rather, the solution lies in the gradual calming of prices and increased emphasis on demand management. This goal and this approach have been occasionally considered (see Dorling, 2014; Cheshire et al, 2014) but are regularly derided as unworkable given that government's emphasis on supporting homeownership has become reconciled to continual price increases, which are now viewed as crucial to consumer confidence and spending. Whilst there has been some recent movement towards demand management, with the introduction of a stamp duty supplement on most buy-to-let investments and changes in the rate of tax relief on privately let properties and second homes (Bank of England, 2016), this is small beer compared with the scale of investment-led housing consumption. The debate on solving the housing crisis must move beyond the current preoccupation with simply building more homes in a forlorn effort to keep pace with credit supply and cash-buying for investment. That is not to say that more homes are not needed in some places or that the current planning system is faultless (Gurran et al, 2016). But greater thought needs to be given to the function of housing. Privately-owned homes will always, in part, be a source of consumer confidence and a store of private wealth. It has not been our intention to present overseas buyers and buy-to-let investors as the villains in our account of London's housing crisis, but their presence provides a clear signal of the changing function of housing. The investment motive is common to all house-purchasing and the complicity of investment in driving up house prices and housing demand has led to the suggestion that capital gains tax might be levied from transactions on main residences, hence bringing the taxation of 'housing into line with other assets' with the purpose of discouraging 'overinvestment' (Barker, 2014: 60). The reasonable expectation of families to benefit from the investment 
potential of housing has to be acknowledged but then balanced with an appreciation of its central role in providing shelter, stability to individuals, families and communities, and long-term social opportunity. Without this rebalanced perspective and a recasting of the function of housing in this unfolding drama there can be no lasting answer to the current housing crisis.

\section{References}

Aalbers, M.B. (2016) The Financialisation of Housing: A Political Economy Approach. Routledge: London. Aoki, B.K., Proudman, J. and Vlieghe, G. (2001) Why house prices matter. Bank of England: London.

Atkinson, R., Burrows, R., \& Rhodes, D. (2016). Capital city? London's housing markets and the "super rich." Handbook on Wealth and the Super-Rich, 225-243.

Bank of England (2015a) Inflation Report Section 1: Money and Asset Prices. http://www.bankofengland.co.uk/publications/Documents/inflationreport/2015/may1.pdf (Accessed 22 June 2016).

Bank of England (2015b) Financial Stability Report: Part A: The UK Housing Market. http://www.bankofengland.co.uk/publications/Documents/fsr/2015/fsr37sec4.pdf (Accessed 22 June 2016).

Bank of England (2016) Consultation Paper CP11/16 Underwriting standards for buy-to-let mortgage contracts. Bank of England: London.

Barker, K. (2014) Housing: Where's the Plan? London Publishing Partnership: London.

Bowie, D. (2017) Radical Solutions to the Housing Supply Crisis, Policy Press: Bristol

Breheny, M. and Hall, P. (Ed) (1996) The People: Where Will They Go? National Report of TCPA Regional Inquiry into Housing Need and Provision in England. Town and Country Planning Association: London

Cameron D (2009) Speech: The Big Society. http://www.conservatives.com/News/Speeches/2009/11/David_Cameron_The_Big_Society.aspx (Accessed 10 January 2011).

Cheshire, P. (2014) Turning houses into gold: the failure of British planning. http://blogs.lse.ac.uk/politicsandpolicy/turning-houses-into-gold-the-failure-of-british-planning/ (accessed 22 June 2016).

Cheshire, P., Nathan, M. and Overman, H. G. (2014) Urban Economics and Urban Policy: Challenging Conventional Policy Wisdom. Edward Elgar: London

DCLG (2016a) Live Tables - Table FT1101 (S101) (Trends in Tenure), accessed 10 November 2016 at https://www.gov.uk/government/uploads/system/uploads/attachment_data/file/538745/

FT1101_Trends_in_tenure.xlsx

DCLG (2016b) House Building: December Quarter 2015, England https://www.gov.uk/government/uploads/system/uploads/attachment data/file/502930/House Building Rel ease Dec Qtr 2015.pdf (Accessed 8 December 2016)

DCLG (2016c) 2014-based Household Projections: England, 2014-2039

https://www.gov.uk/government/uploads/system/uploads/attachment data/file/536702/Household Projecti ons - 2014 - 2039.pdf (Accessed 8 December 2016)

DCLG (2016d) Evaluation of the Help to Buy Equity Loan Scheme. DCLG: London.

Dorling, D. (2014) All that is Solid: The Great Housing Disaster, Penguin: Harmondsworth

Duca, J. V., Muellbauer, J. and Murphy, A. (2010) Housing markets and the financial crisis of 2007-2009: Lessons for the future, in Journal of Financial Stability, 6, 4, pp. 203-217.

Edwards, M. (2002) Wealth creation and poverty creation, in City, 6, 1, pp. 25-42

Edwards, M. (2015) Prospects for Land, Rent and Housing in UK Cities. Government Office for Science: London

Edwards, M. (2016) The housing crisis and London, in City, 20, 2, pp. 222-237

Evans, A. W. (1991) Rabbit Hutches on Postage Stamps': Planning, Development and Political Economy, in Urban Studies, 28, 6, pp. 853-870.

Fernandez, R., Hofman, A., \& Aalbers, M. B. (2016). London and New York as a safe deposit box for the transnational wealth elite, in Environment and Planning A, 48, 12, pp. 2443-2461.

Frydman, R. and Goldberg, M.D. (2011) Beyond Mechanical Markets: Asset price swings, risk and the role of the state, Princeton University Press: Princeton. 
Gallent, N. (2016) Investment, global capital and other drivers of England's housing crisis, in Journal of Urban Regeneration and Renewal 9, 20, pp. 122-138.

Giles, C. (2013) IMF says Help to Buy risks inflating prices. The Financial Times. http://www.ft.com/cms/s/0/6f8c2d50-30f3-11e3-b478-00144feab7de.html\#axzz49TD8QhrE (Accessed 24 June 2016).

Gurran, N., Gallent, N. and Chui, R. (2016) Politics, Planning and Housing Supply in Australian, England and Hong Kong. Routledge: London and New York.

Hall, P. (2014) Why are the great 'stuck sites' stuck? In Adonis A, Rogers, B and Sims S (Ed) Go East: Unlocking the Potential of the Thames Estuary. Centre for London: London. pp. 60-71.

Healey, J. (2015) High aspirations, sound foundations: a discussion report on the centre-ground case for building 100,000 new public homes. The Smith Institute: London.

Hilber, C.A.L. and Vermeulen, W. (2010) The Impacts of Restricting Housing Supply on House Prices and Affordability - Final Report. DCLG: London.

Hilber, C. (2015) UK Housing and Planning Policies: The Evidence from Economic Research, LSE: London

Holmans, A.E. (2014) Housing need and effective demand in England: A look at 'the big picture'. Cambridge Centre for Housing and Planning Research: Cambridge.

Hunter, P. (2016) The Englishman's castle and the impact of foreign investment in residential property. in Raco M. (Ed) Britain for sale? Perspectives on the cost and benefits of foreign ownership. The Smith Institute: London. pp. 41-50.

Jackson, B. (2005) Revisionism reconsidered: 'Property-owning democracy' and egalitarian strategy in post-war Britain in Twentieth Century British History, 16, 4, pp. 416-440

Jordá, O., Schularick, M. and Taylor, A.M. (2011) Financial crises, credit booms and external imbalances: 140 years of lessons, in IMF Economic Review 59, 2, pp. 340-378.

Kemp, P. A. and Kofner, S. (2010) Contrasting Varieties of Private Renting: England and Germany, in International Journal of Housing Policy, 10, 4, pp. 379-398.

Knight Frank (2016) Residential Research: Global House Price Index, Q2 2016, Frank Knight: London

Lyons Housing Review (2014) Mobilising across the nation to build the homes our children need, accessed 10 November 2016 at http://www.yourbritain.org.uk/uploads/editor/files/The Lyons Housing Review 2.pdf

Mace, A., Blanc, F., Gordon, I. and Scanlon, K. (2016) A 21st Century Metropolitan Greenbelt, London School of Economics: London

Machin, S. (2015 Real Wage Trends Understanding the Great Recession: From Micro to Macro Conference, $\begin{array}{llllll}\text { Bank of } & \text { England, } & \text { September } & 23 & \text { and }\end{array}$ https://www.ifs.org.uk/uploads/Presentations/Understanding\%20the\%20recession 230915/SMachin.pdf (Accessed 29th November 2016).

McLeay, M., Radia, A., and Thomas, R. (2014) Money creation in the modern economy. Quarterly Bulletin. Q1. The Bank of England: London.

Meen, G. (2011) A Long-Run Model of Housing Affordability, in Housing Studies, 26, 7/8, pp. 1081-1103.

Niemietz, K. (2016) Liberating the housing market through fiscal decentralisation http://www.iea.org.uk/blog/liberating-the-housing-market-through-fiscal-decentralisation (Accessed 4 April 2016).

ONS (2016) House Price Index September 2016, Figure 2: Average UK house price, January 2005 to September 2016 http://www.ons.gov.uk/economy/inflationandpriceindices/bulletins/housepriceindex/sept2016 (Accessed 1st December 2016)

Payne, S. (2013) Pioneers, pragmatists and sceptics: speculative housebuilders and brownfield development in the early twenty-first century, in Town Planning Review, 84, 1, pp. 37-62.

Piketty, T. (2014) Capital in the Twenty-First Century. Harvard University Press: Cambridge MA.

Reinhart, K. and Rogoff, C. (2011) This Time is Different: Eight Centuries of Financial Folly. Princeton University Press: Princeton.

Rossall Valentine, D. (2015) Solving the UK Housing Crisis, The Bow Group: London

RICS (2014) RICS Policy Position: Help to Buy. http://www.rics.org/Global/RICS\%20Policy\%20Position\%20\%20Help\%20to\%20Buy.pdf (Accessed 22 June 2016).

Ryan-Collins, J., Greenham, T., Werner, R. and Jackson, A. (2012) Where does money come from? http://www.neweconomics.org/publications/entry/where-does-money-come-from (Accessed 22 June 2016). 
Tunstall, B. (2015) Relative housing space inequality in England and Wales, and its recent rapid resurgence, in International Journal of Housing Policy, 15, 2, pp. 105-126.

Turner, G. (2008) The Credit Crunch: Housing Bubbles, Globalisation and the Worldwide Economic Crisis. Pluto Books: London.

Wainwright, T. (2009) Laying the foundations for a crisis: Mapping the historico-geographical construction of Residential Mortgage Backed Securitization in the UK, in International Journal of Urban and Regional Research, 33, 2, pp. 372-388.

White, A. (2015) Investors start flipping Battersea Power Station flats - and they're not even built yet, in The Telegraph. http://www.telegraph.co.uk/finance/property/house-prices/11407252/Investors-start-flippingBattersea-Power-Station-flats-and-theyre-not-even-built-yet.html (Accessed 22 June 2016).

Whitehead, C.M.E. (1991) From Need to Affordability: An Analysis of UK Housing Objectives, in Urban Studies, 28, 6, pp. 871-887.

Whitehead, C.M.E. (2016) Using projections of household numbers - tensions between planning and economics, in Town and Country Planning, 85, 10, pp.415-421

Williams Z. (2016) Donald Trump has thrown caution to the wind. So must the left. The Guardian. http://www.theguardian.com/commentisfree/2016/mar/06/donald-trump-caution-to-wind-leftwingersstymied-pedantic-reserve (Accessed 20 June 2016). 